\title{
Radiological data on building stones from a Spanish region: Castilla y León
}

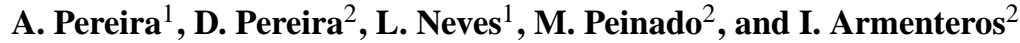 \\ ${ }^{1}$ IMAR, Dept. Ciências da Terra, Universidade de Coimbra, Portugal \\ ${ }^{2}$ Departamento de Geología, Universidad de Salamanca, Spain
}

Correspondence to: D. Pereira (mdp@usal.es)

Received: 17 July 2013 - Published in Nat. Hazards Earth Syst. Sci. Discuss.: 14 August 2013

Revised: 1 November 2013 - Accepted: 17 November 2013 - Published: 23 December 2013

\begin{abstract}
As construction and building material, natural stone has a great potential to promote the commercial activities of certain European regions. Such is the case of Castilla y León in Spain, where many different rocks, ranging from sedimentary to metamorphic and igneous, are commercialized for building purposes. However, to be able to compete in a market subject to an economic crisis, highly exacerbated in the construction sector, and to compete with the lower prices offered by emerging countries, the issue would be to make the Spanish offer more attractive. Here we propose a complete characterization of rocks regarding their radiological properties, which are related to their mineralogy and geochemistry. Rocks emit natural radioactivity, and the presence of $\mathrm{Rn}$ and its decay products in dwellings has become an important issue in North America and Europe owing to its relationship with the carcinogenic effects of this gas. Although most of the studied rocks comply with the $I$ parameter proposed in the European Norm 112 for Radiological Protection (accepted value $I \leq 1$; average for sedimentary rock: $I=0.22$, SD 0.14; average for metamorphic rocks: $I=0.70$, SD 0.48; average for igneous rock: $I=0.86$, SD 0.22 ), the inclusion of a proper radiological characterization in the list of characteristics would guarantee quality and safety in their use in comparison with products lacking this information. Some natural stones have been demonized for the potential exhalation of natural radioactivity, and the different parameters used should be addressed in a more systematic way.
\end{abstract}

\section{Introduction}

The carcinogenic effects of radon gas on the human population have been clearly established (Lubin et al., 1994; Darby et al., 1995; Krewski et al., 2006; Chen et al., 2011), and this has prompted many countries to address the question of the presence of radon inside dwellings in their territories (Gillmore and Jabarivasal, 2010). It is also well known that radon is the largest single contributor to exposure of the public to natural radiation (UNSCEAR, 1993). However, despite the large dataset already available for radon in soil, water and air, only limited work has been published in the international scientific literature on radon concentrations in natural building stone in general (Pavlidou et al., 2006) and in Spanish ornamental stone in particular (Pereira et al., 2011). In this latter case the exceptions are certain widely commercialized stones (i.e. Rosa Porriño granite, from Galicia), and even in this case some data and locations have been found to be incorrect (Pereira et al., 2011).

Natural stone is the most important natural resource in Castilla y León, Spain (SIEMCALSA, 2008). The sector employs more than seven thousand people directly or indirectly, and a large amount of the product (up to $20 \%$ ) is exported, mainly within Europe (http://www.pinacal.es/ingles/ index.asp, last seen on 6 August 2013). Different lithologies are found in this area, ranging from sedimentary to igneous and metamorphic rocks (Fig. 1). For many years the building sector has been an important driver of the economy, some of the quarries being used both for new construction and for restoration, since many cities in the area have been acknowledged as belonging to the UNESCO World Heritage (Pereira and Cooper, 2013) and restorations involving the 


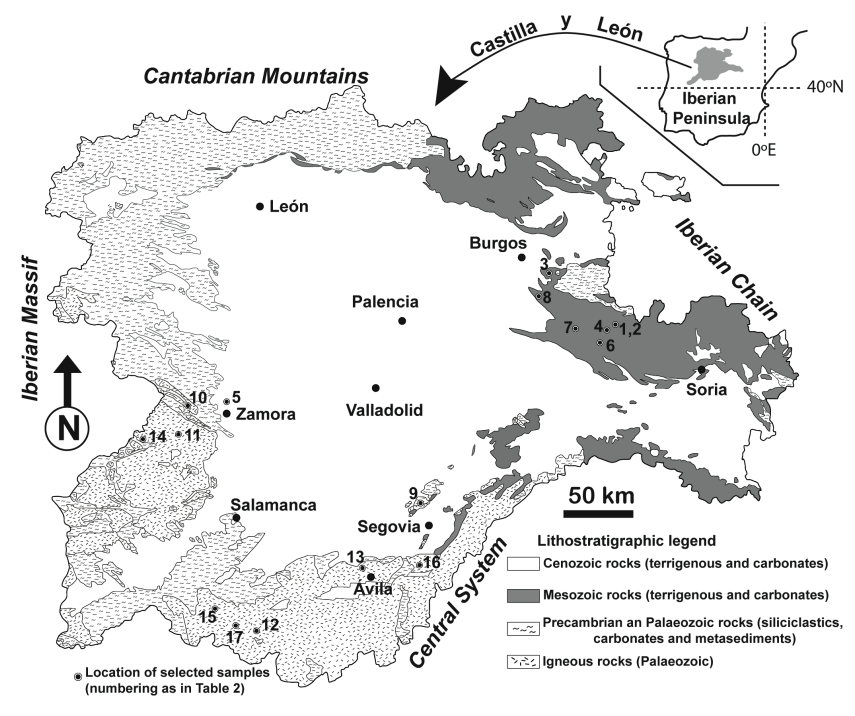

Fig. 1. Simplified geological map of Castilla y León, showing the disposition of all lithologies studied in the present paper. Modified from Cabrera Señal et al. (1997).

replacement of slabs and ashlars must necessarily use the original local natural stone. The buildings are constructed using the local stone, mainly sandstone and limestone, but several granites are used as the bottom ashlars because of the problems arising from the capillary absorption of damp by those sedimentary stones (del Arco et al., 1987; Iñigo et al., 2003; Schillaci et al., 2008). Some polished decorative stone slices are also present on some of the buildings. The exterior use of building stone is not a problem regarding radioactivity, since radon escapes into the atmosphere. Radon exhalation is a normal occurrence, and the terrestrial atmosphere contains a low but fairly constant level of the radioactive gas. After several days of residence time in the atmosphere, ${ }^{222} \mathrm{Rn}$ naturally decays to ${ }^{218} \mathrm{Po}$, a metallic radionuclide that falls back to the ground with dust and rain over a period of hours/days (Liang et al., 2004). However, the increasing practice of using natural stone as polished slabs for pavement and worktops in both kitchens and bathrooms instead of other synthetic materials, which were very popular years ago, has raised the question about health security related to the possible exhalation of radon coming from these natural stones. Natural radioactivity is associated with many different rocks, mainly due to the accessory minerals they contain (e.g. Whitfield et al., 1959; Anjos et al., 2005). Our rocks have a variety of minerals, some of them having radiogenic elements in their stoichiometric formulas and some being possible receptors of radiogenic elements owing to their mineral structure. The goal of this study is to assess the radiological risk associated with the natural stones used in the region of Castilla y León on the basis of the activity of the ${ }^{226} \mathrm{Ra},{ }^{232} \mathrm{Th}$ and ${ }^{40} \mathrm{~K}$ radioisotopes as well as the radon exhalation rate from the same samples. Exhaustive studies addressing the petrography to these stones, combined with geochemical and radiological studies, were performed to help us to differentiate between totally harmless rocks and rocks that would have to be labelled very clearly if placed on the market.

The paper is organized as follows. We first introduce the analytical procedure for analysing all radiological parameters used for the purpose of this natural stone characterization; we then summarize the main mineralogical characteristics of the targeted rocks, as they can be crucial in their radiological signature. Following we present the results and the discussion, where a clear significance is attributed to the origin of the rocks and their weathering state in relation to the resulting radiological values.

\section{Analytical methods}

PINACAL (a consortium of natural stone companies from Castilla y León) offered us a set of 26 blocks of natural stones commercialized in the region. These samples were part of a student's final dissertation project (Manteca, 2011), for which we analysed the major and trace elements and calculated the $I$ parameter from the $\mathrm{U}$, Th and K contents. From this dataset, a selection of 17 samples was analysed for ${ }^{214} \mathrm{Bi},{ }^{208} \mathrm{Tl}$ and ${ }^{40} \mathrm{~K}$ activity and ${ }^{222} \mathrm{Rn}$. One of the goals was the evaluation of the relationship between radium and its progeny, a more precise approach than using only the parent element since secular equilibrium must be assumed in the long-lived isotope series.

Isotopic activities were estimated using an Ortec $\mathrm{NaI}(\mathrm{Tl})$ detector $(7.6 \mathrm{~cm})$ protected from background radiation with a lead shield at the Laboratory of Natural Radioactivity of the University of Coimbra. The samples $(0.5 \mathrm{~kg})$ were prepared at a grain size of less than $0.5 \mathrm{~mm}$, placed in $0.2 \mathrm{~L}$ Marinelli beakers (internal surface area of $0.0219 \mathrm{~m}^{2}$ ) and left for one month for equilibrium in the ${ }^{226} \mathrm{Ra}$ chain to be reached before measurements were taken. Counting was performed over $10 \mathrm{~h}$ and the spectra were processed with Scintivison-32 software. The background was evaluated using a Marinelli beaker filled with a radionuclide-free material (pure quartz) under the same analytical conditions, and subsequently subtracted from all samples. Calibration was achieved using standards from the International Atomic Energy Agency: RGK-1 (potassium sulphate), RGU-1 (diluted uranium ore) and RGTH-1 (diluted thorium ore) of known composition and activities. $\mathrm{K}$ was evaluated from the ${ }^{40} \mathrm{~K}$ peak $(1460.8 \mathrm{keV})$, $\mathrm{U}$ from the ${ }^{214} \mathrm{Bi}$ peak $(1764.5 \mathrm{keV})$, and Th from the ${ }^{208}$ Tl peak $(2614.5 \mathrm{keV})$, assuming secular equilibrium. Uncertainties are strongly dependent on the radionuclide concentration. The average uncertainties observed in this study were $3.6 \%$ for ${ }^{40} \mathrm{~K}, 11.5 \%$ for ${ }^{214} \mathrm{Bi}$ and $36 \%$ for ${ }^{208} \mathrm{Tl}$. 
Radon exhalation was determined from the same powder samples (previously dried in an oven for $24 \mathrm{~h}$ at $40^{\circ} \mathrm{C}$ ). Samples $(0.5 \mathrm{~kg}$ in weight) were placed inside a $12 \mathrm{~L}$ capacity radon-proof container made of stainless steel for 4 weeks. The concentration of radon was then measured with an AlphaGuard Pro monitor and the exhalation rate was estimated according to the following equation:

$E_{\mathrm{r}}=\left(\left(C_{\mathrm{r}} \cdot V\right) / W\right) \lambda$,

where $E_{\mathrm{r}}$ is the exhalation rate $\left(\mathrm{Bq} \mathrm{kg}^{-1} \mathrm{~h}^{-1}\right), C_{\mathrm{r}}$ is the equilibrium radon concentration in the container $\left(\mathrm{Bq} \mathrm{m}^{-3}\right), V$ is the free volume of the container $(\mathrm{L}), W$ is the weight of the sample $(\mathrm{kg})$, and $\lambda$ is the radon decay constant $\left(\mathrm{h}^{-1}\right)$. Uncertainties varied between 10 and $20 \%$ for the typical range of values measured in this work.

A detailed petrographic study using a Leica microscope with a coupled digital camera was used to reproduce the most interesting features of our natural stones.

\section{The rocks}

The rocks studied are described in detail in García de los Ríos and Báez Mezquita (2001) and here we summarize the mineralogy, since this is assumed to be the main factor controlling $\mathrm{Rn}$ exhalation in most rocks.

\subsection{Sedimentary rocks}

Sedimentary rocks are very important in this region and they have been used to sculpt the façade work on most historical buildings. The radiological measures in sedimentary rocks were performed on the principal rock types used in Castilla y León and neighbouring regions as building stones: siliciclastic sandstones, a conglomerate, and limestones.

\subsubsection{Sandstones}

The sandstones studied correspond to feldspathic litharenites (Folk, 1965). In decreasing order of abundance the grains consist of quartz, rock fragments (schists, polycrystalline quartz), feldspars (orthose and plagioclase), and micas (muscovite and biotite) as the major components, with accessory minerals such as iron oxides, tourmaline, zircon and/or rutile. The matrix content commonly represents more than $30 \%$ and is formed by small crystals of mica and clays. Some of these rocks are patchily cemented by iron oxides and barite.

\subsubsection{Conglomerate}

We included a conglomerate that has been quarried since Roman times and that has been used for important historical buildings in Spain. The peculiarity of this conglomerate is that it is fully cemented by a mosaic of calcite and is known as Mármol de Espejón (Espejón Red Marble).

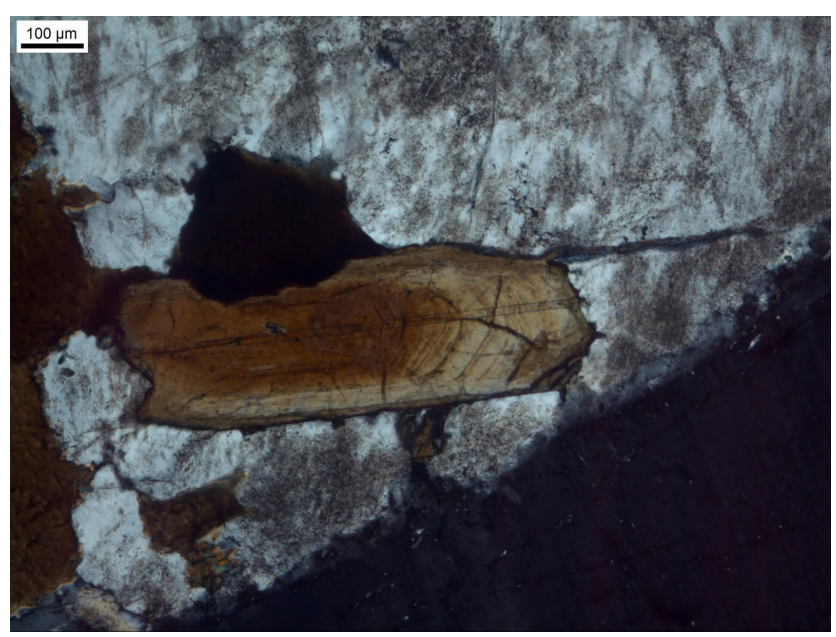

Fig. 2. Allanite $(\mathrm{Ce}, \mathrm{Ca}, \mathrm{Y}, \mathrm{La})_{2}\left(\mathrm{Al}, \mathrm{Fe}^{+3}\right)_{3}\left(\mathrm{SiO}_{4}\right)_{3}(\mathrm{OH})$ in the Cardeñosa granite, crossed nicols.

\subsubsection{Limestones}

Limestones are quarried both for new constructions and for the restoration of historical buildings. The main types are dolomicrites (i.e. Silos stone) and biocalcarenites with abundant fossils (i.e. Hontoria limestone, Campaspero limestone) (Folk, 1959).

\subsection{Igneous and metamorphic rocks}

The igneous (granites and granitic rocks) and metamorphic (phyllite and gneiss) rocks analysed in this work cover the whole variety present in the region.

Within the granitic rocks, the most common types are monzogranites and several leucogranites and granodiorites, made up of quartz, potassium feldspar, plagioclase, different micas, possible amphibole and different accessory phases. All of them have biotite, and muscovite is present in more evolved and aluminium-rich rocks, where cordierite can also be found. Hornblende appears in minor amounts in several granodiorites. These granitic rocks show diverse microstructures, from fine-grained equigranular types to porphyritic facies, where large crystals of potassium feldspar are found.

From a petrographic and petrogenetic point of view, the granitic rocks studied belong to different families. One of them was mainly formed by the melting of metasediments and the other is a hybrid type, formed by a mixture of sources. The former contains accessory minerals such as zircon, xenotime and monazite. $\mathrm{U}$ and $\mathrm{Th}$ are present in their mineral lattice. In addition to the above accessories, the latter contains allanite (Fig. 2), epidote, and sometimes thorite. The formula of allanite reveals the presence of a significant amount of rare-earth elements, some of them highly radioactive, plus some $\mathrm{U}$ and $\mathrm{Th}$. 
One particular case is Rojo Sayago, a porphyritic granite transformed into epysienite (Le Maitre et al., 1989), where calcic plagioclase has been converted into albite, biotite into chlorite and the iron contained within the potassium feldspar has been oxidized. All these changes are due to local lowtemperature hydrothermal metamorphism. Zircon appears mostly within other mineral phases, although its accumulation has also been observed in deformation structures (Fig. 3a and $b$ ).

The gneiss from the province of Zamora belongs to the socalled "Ollo de Sapo" formation, a previous igneous rock that has been deformed and recrystallized (Castro et al., 2000). It shows a gneissic structure, is medium- to coarse-grained and it is characterized by potassium feldspar crystals as large as 3-4 cm, surrounded by a foliation formed of muscovite and biotite. Other porphyroclasts are albite-oligoclase and bluish quartz; accessory minerals such as zircon, titanite, ilmenite and monazite are common. The accessory minerals are usually related to biotite, forming micronodules with it.

The phyllite is a metasedimentary rock of Neoproterozoic age. It is fine- to very fine-grained, showing a well-developed schistosity. It is made up of phyllosilicates (e.g. phengite, chlorite and minor biotite), and contains apatite, tiny zircon crystals and ilmenite as accessory minerals.

\section{Results}

In a previous study involving 20 samples, each of them related to a different ornamental stone, Manteca (2011) established the possible use of the rocks on the basis of their radiological risk by determining the $I$ index proposed in Norm 112. As expected, igneous and metamorphic rocks showed similar averages, being the highest of the global dataset, but they also showed differences as regards to variance, which was much higher in the metamorphic group than in the igneous type (Table 1). Lithology should be the main factor controlling variability since in the latter case granites were the only rock type present (coefficient of variation of 0.26) while the metamorphic group comprised graniterelated rocks, such as gneisses, but also a phyllite and a quartzite; this last rock type had the minimum value $(I=$ $0.16)$ while the highest $(I=1.08)$ was measured in the gneissic rock. These values are slightly higher than the level demanding action in Norm 112, and the same conclusion applies for two samples of the igneous group (the highest value of $I=1.24$; Manteca, 2011).

The global average for the sedimentary rocks $(I=0.22)$ was lower than for those of the igneous and the metamorphic group, but showed the highest variance in the dataset (coefficient of variation of 0.65 ). This variance was also related to the lithology, composed of sandstones, limestones and a conglomerate. Accordingly, the rock composition and the U, $\mathrm{Th}$ and $\mathrm{K}$ content are the main factors that control the $I$ parameter.
Table 1. I values for natural stones from Castilla y León (Manteca, 2011).

\begin{tabular}{lrrr}
\hline & Sedimentary & Metamorphic & Igneous \\
\hline Average & 0.22 & 0.70 & 0.86 \\
Median & 0.22 & 0.86 & 0.87 \\
Standard deviation & 0.14 & 0.48 & 0.22 \\
Coefficient of variation & 0.65 & 0.69 & 0.26 \\
Minimum & 0.01 & 0.16 & 0.59 \\
Maximum & 0.47 & 1.08 & 1.24 \\
$N$ & 14 & 3 & 9 \\
\hline
\end{tabular}

The results of the ${ }^{226} \mathrm{Ra},{ }^{232} \mathrm{Th}$ and ${ }^{40} \mathrm{~K}$ activity in the selected set of 17 samples are shown in Table 2 . The ${ }^{222} \mathrm{Rn}$ exhalation rate obtained for each sample is also included in the same table. Owing to the low number of samples in the metamorphic group $(n=2)$ and because the results were similar to those observed in the igneous rocks, both rock types are discussed together.

The isotope activities and radon exhalation rate displayed the same pattern, characterised by lower values for the sedimentary samples and higher ones for the igneous and metamorphic group. Sandstones, limestones and the conglomerate show varying ${ }^{226} \mathrm{Ra}$, between less than the detection limit for the technique used up to $27.1 \mathrm{~Bq} \mathrm{~kg}^{-1}$, with an average of $15.1 \mathrm{~Bq} \mathrm{~kg}^{-1}$. In this group the lowest values were found in the carbonate rocks and in the conglomerate, as expected; the sandstones showed the highest activities. For the same rock types, ${ }^{232} \mathrm{Th}$ and ${ }^{40} \mathrm{~K}$ showed a similar variability, with a maximum of $25.2 \mathrm{~Bq} \mathrm{~kg}^{-1}$ and $749.5 \mathrm{~Bq} \mathrm{~kg}^{-1}$, respectively. The estimated average for ${ }^{232} \mathrm{Th}$ was $9.5 \mathrm{~Bq} \mathrm{~kg}^{-1}$ and $301.9 \mathrm{~Bq} \mathrm{~kg}^{-1}$ for ${ }^{40} \mathrm{~K}$. The radon exhalation rate was also variable, between less than the detection limit up to $0.017 \mathrm{~Bq} \mathrm{~m}^{-2} \mathrm{~h}^{-1}$, with an average of $0.005 \mathrm{~Bq} \mathrm{~m}^{-2} \mathrm{~h}^{-1}$. As before, the lowest values were measured in the carbonates.

The igneous-metamorphic group showed higher values for all the parameters analysed. The ${ }^{226} \mathrm{Ra}$ activity ranged from $39.0 \mathrm{~Bq} \mathrm{~kg}^{-1}$ to $118.4 \mathrm{~Bq} \mathrm{~kg}^{-1}$, with an average of $68.8 \mathrm{~Bq} \mathrm{~kg}^{-1}$. The average for ${ }^{233} \mathrm{Th}$ activity was close to that of the preceding isotope $\left(60.0 \mathrm{~Bq} \mathrm{~kg}^{-1}\right)$ and ranged from 11.7 to $86.2 \mathrm{~Bq} \mathrm{~kg}^{-1}$. As usual, ${ }^{40} \mathrm{~K}$ displayed the highest activities, varying between $919.6 \mathrm{~Bq} \mathrm{~kg}^{-1}$ to $1861.3 \mathrm{~Bq} \mathrm{~kg}^{-1}$ and the average is $1202.9 \mathrm{~Bq} \mathrm{~kg}^{-1}$. The radon exhalation rate varied from 0.002 to $0.395 \mathrm{~Bq} \mathrm{~kg}^{-1} \mathrm{~h}^{-1}$, with an average of $0.079 \mathrm{~Bq} \mathrm{~kg}^{-1} \mathrm{~s}^{-1}$. The phyllite rock values, for all the parameters analysed, did not differ from those observed in granites or granitic-related rocks, as is the case with the gneiss.

\section{Discussion}

Overall, the results are in agreement with what was expected in light of the type of rocks studied. The highest radionuclide activities were observed in the igneous group and for 

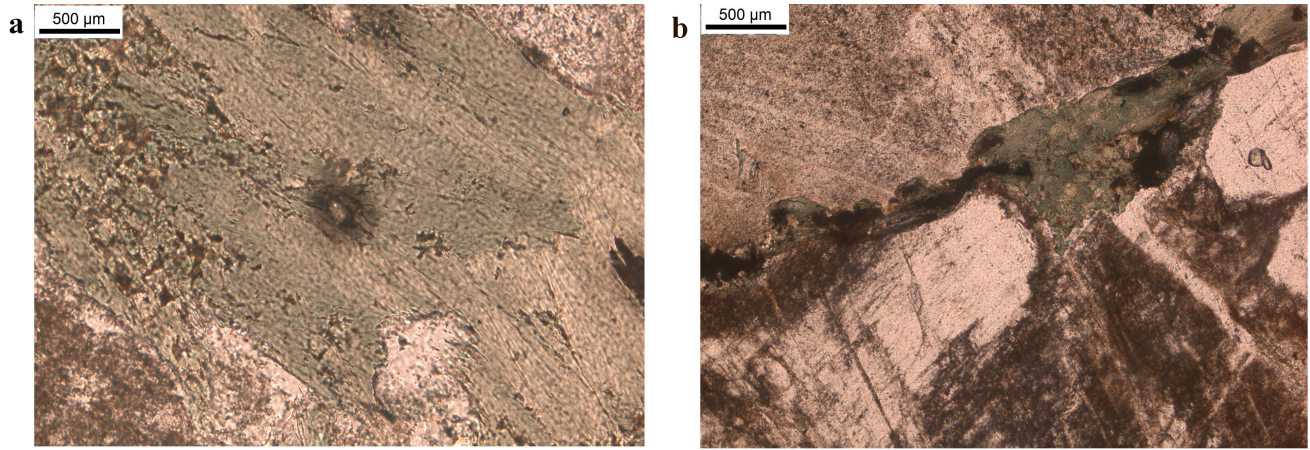

Fig. 3. (a) Zircon in chlorite, parallel nicols; (b) Zircon in deformation structure, parallel nicols.

Table 2. U, ${ }^{226} \mathrm{Ra},{ }^{232} \mathrm{Th},{ }^{40} \mathrm{~K}$ and $\mathrm{Rn}$ exhalation in the powdered samples of natural stone studied (only for the 17 selected samples). Commercial names have been kept in Spanish for easier referencing in the original literature. \# is location in Fig. 1; b.d.l. is below detection limit.

\begin{tabular}{rllrrrrr}
\hline$\#$ & Commercial & Lithology & $\begin{array}{r}\mathrm{U} \\
\text { name }\end{array}$ & $\begin{array}{r}{ }^{226} \mathrm{Ra} \\
\left(\mathrm{mg} \mathrm{kg}^{-1}\right)\end{array}$ & $\begin{array}{r}{ }^{232} \mathrm{Th} \\
\left(\mathrm{Bq} \mathrm{kg}^{-1}\right)\end{array}$ & $\begin{array}{r}{ }^{40} \mathrm{~K} \\
\left(\mathrm{~Bq} \mathrm{~kg}^{-1}\right)\end{array}$ & $\begin{array}{r}\text { Exhalation rate } \\
\left(\mathrm{Bq} \mathrm{kg}^{-1} \mathrm{~h}^{-1}\right)\end{array}$ \\
\hline 1 & Arenisca Quintanar & Sandstone & 1.7 & 21.3 & 7.8 & 485 & 0.002 \\
2 & Quintanar beige & Sandstone & 0.7 & 9.0 & 9.1 & 332 & 0.004 \\
3 & Rojo San Adrián & Sandstone & 2.2 & 27.1 & 25.2 & 749 & 0.009 \\
4 & Sierra Demanda & Sandstone & 1.8 & 22.6 & 6.0 & 410 & 0.005 \\
5 & Zamora & Sandstone & 0.8 & 23.4 & 23.7 & 439 & 0.017 \\
6 & Espejón & Conglomerate & 0.5 & 6.2 & 2.9 & b.d.1. & 0.003 \\
7 & Silos & Limestone & 0.9 & 11.5 & b.d.1. & b.d.1. & 0.000 \\
8 & Hontoria & Limestone & b.d.1. & b.d.1. & 1.3 & b.d.1. & 0.000 \\
9 & Filita Bernardos & Phyllite & 4.5 & 55.7 & 65.3 & 1016 & 0.017 \\
10 & Gneis Zamora & Gneis & 6.3 & 77.6 & 68.8 & 1421 & 0.122 \\
11 & Rojo Sayago & Episienite & 4.3 & 53.6 & 86.2 & 1861 & 0.395 \\
12 & Azul noche & Granite & 4.8 & 59.7 & 50.8 & 954 & 0.002 \\
13 & Rubio Cardeñosa & Granite & 3.2 & 39.0 & 11.7 & 1201 & 0.066 \\
14 & Silvestre Dorado & Granite & 9.6 & 118.4 & 53.3 & 1335 & 0.030 \\
15 & Los Santos & Granite & 6.8 & 75.5 & 71.9 & 1123 & 0.044 \\
16 & Gris Villa & Granite & 5.2 & 64.8 & 68.8 & 920 & 0.024 \\
17 & Sorihuela & Granite & 6.1 & 75.3 & 63.6 & 994 & 0.012 \\
\hline
\end{tabular}

the granite-related metamorphic rock. Radon exhalation followed the same trend, increasing as ${ }^{226} \mathrm{Ra}$ increased in these rocks.

The results obtained in this study are also in agreement with data reported for rocks from similar geological settings (Abbady, 2004; Ahmed et al., 2006).

Uranium and thorium often share a common mineralogy, and this was tested through the evaluation of the mutual relationship between the isotopes included in their decay chains and analysed in the present study; the relationship with potassium through the ${ }^{40} \mathrm{~K}$ isotope was also investigated. The results are expressed in Figs. 4 to 6.

In all cases the samples cluster into two main groups, one for the sedimentary rocks with the lowest activities and, on the opposite side of the graphs, the igneous and metamorphic rocks. The rocks analysed show a significant correlation between isotopic activities, and define in some cases an approximately linear trend. This suggests that the radionuclides could share a common mineralogy. Following the above-mentioned petrographic description, the radioisotopes should mostly be contained in the mineralogical fraction composed by zircon, xenotime, monazite, allanite, titanite, apatite and micas, mainly biotite.

Some samples, however, deviate clearly from the linear trend, such as Silvestre Dorado and Rubio Cardeñosa, both showing a slight enrichment in ${ }^{226} \mathrm{Ra}\left({ }^{226} \mathrm{Ra} /{ }^{232} \mathrm{Th}\right.$ is of 3.3 and 2.2, respectively), while Rojo Sayago is depleted in the same radioisotope $\left({ }^{226} \mathrm{Ra} /{ }^{232} \mathrm{Th}\right.$ is of 0.6$)$. This latter rock, reddish in colour, shows evidence of the hydrothermal alteration that transformed biotite into chlorite and plagioclase into carbonates and epidote, dissolving the quartz and leaving a high percentage of porosity. In fact, the proper 


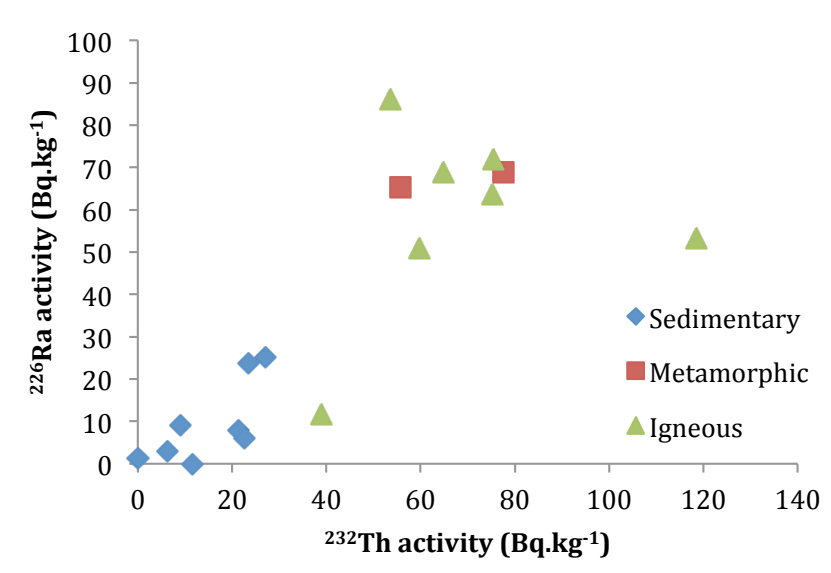

Fig. 4. ${ }^{226} \mathrm{Ra}$ and ${ }^{232} \mathrm{Th}$ activity for the studied samples, in $\mathrm{Bq} \mathrm{kg}^{-1}$.

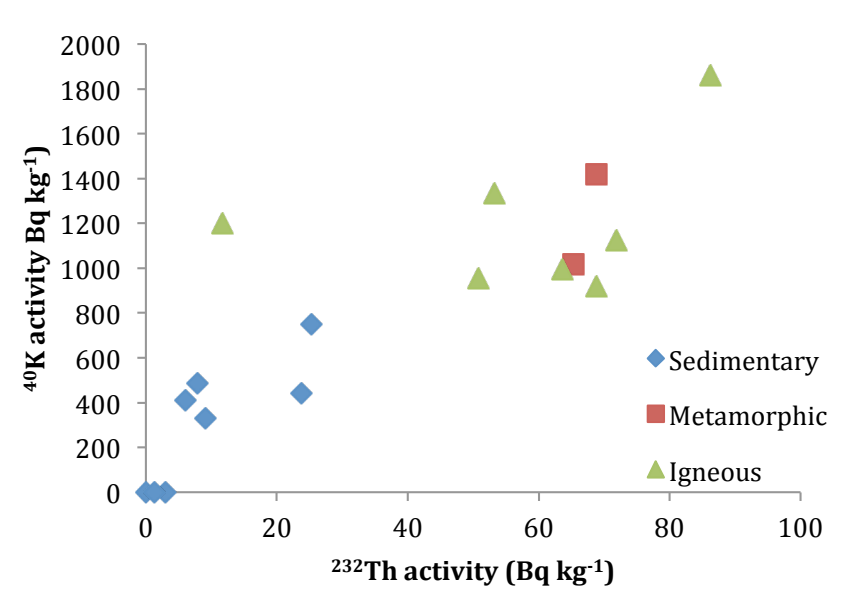

Fig. 5. ${ }^{232} \mathrm{Th}$ and ${ }^{40} \mathrm{~K}$ activity for the studied samples, in $\mathrm{Bq} \mathrm{kg}^{-1}$.

terminology for this rock should be "episienite" instead of granite, and the hydrothermal alteration can explain the removal of the uranium, probably carried out by hot fluids. For the other granites, the explanation for the observed geochemical behaviour could be related to the presence of uraniumbearing minerals.

The correlation of ${ }^{226} \mathrm{Ra}$ activity with radon exhalation also shows a linear trend, but with some samples deviating from such linearity (Fig. 7). Three of them, all included in the igneous and metamorphic group, differ significantly due to an increased radon exhalation rate for equivalent radioisotope activity. This may be related to the mineralogical distribution of ${ }^{226} \mathrm{Ra}$ (and uranium) in the rocks. The highest radon exhalation rate was measured in the Rojo Sayago reddish granite, which allowed us to conclude that despite the lower ${ }^{226}$ Ra activity (and uranium content; Manteca, 2011) the changes in rock mineralogy (imposed by hydrothermal fluids and the tectonics, increasing the porosity and leading to a probable redistribution of the uranium-chain isotopes in

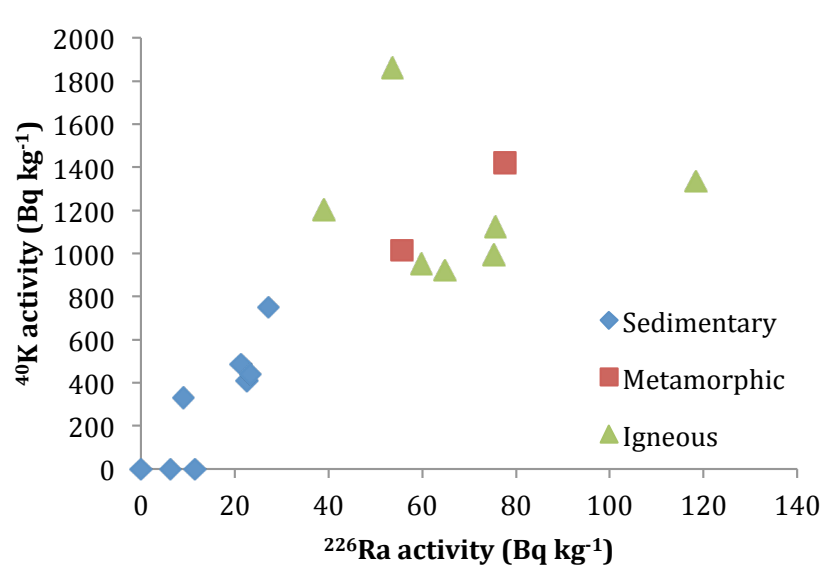

Fig. 6. ${ }^{226} \mathrm{Ra}$ and ${ }^{40} \mathrm{~K}$ activity in $\mathrm{Bq} \mathrm{kg}^{-1}$ for the studied samples.

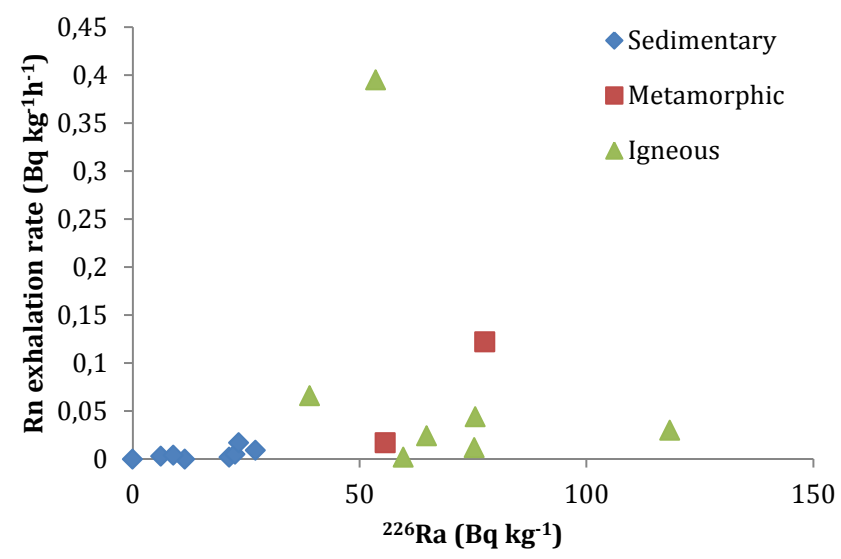

Fig. 7. ${ }^{226} \mathrm{Ra}$ activity in $\mathrm{Bq} \mathrm{kg}^{-1}$ and radon exhalation rate in $\mathrm{Bq} \mathrm{kg}{ }^{-1} \mathrm{~h}^{-1}$ for the studied samples.

the rock) induced a strong increase in the ability of the rock to emanate radon gas. It is highly likely that a redistribution of the long-lived radiosotopes of the uranium decay chain also occurred in the mineralogy of Rubio Cardeñosa sample since this also shows a greater increase in the ${ }^{222} \mathrm{Rn} /{ }^{226} \mathrm{Ra}$ ratio than expected. Tectonic deformation may be another key factor influencing the increase in the ${ }^{222} \mathrm{Rn} /{ }^{226} \mathrm{Ra}$ ratio, as observed in the case of the Zamora Gneiss sample.

By contrast, the Silvestre Dorado sample revealed the opposite trend, showing an unexpected decrease in the above ratio, with a radon exhalation rate lower than that measured, for instance, in the Rubio Cardeñosa $\left(0.03 \mathrm{~Bq} \mathrm{~kg} \mathrm{~h}^{-1}\right.$ vs. $0.07 \mathrm{~Bq} \mathrm{~kg} \mathrm{~h}^{-1}$, respectively). While the latter showed the lowest ${ }^{226} \mathrm{Ra}$ activity in the igneous and metamorphic group (39 $\mathrm{Bq} \mathrm{kg}^{-1}$ ), the Silvestre Dorado, in the same group, had the highest activity $\left(118.4 \mathrm{~Bq} \mathrm{~kg}^{-1}\right)$. Rocks that have a high radon exhalation rate do not necessarily exhale dangerous amounts of the gas (http://www.sustainable-design.ie/arch/ radon.htm, last seen 19 November 2012). This is always been 


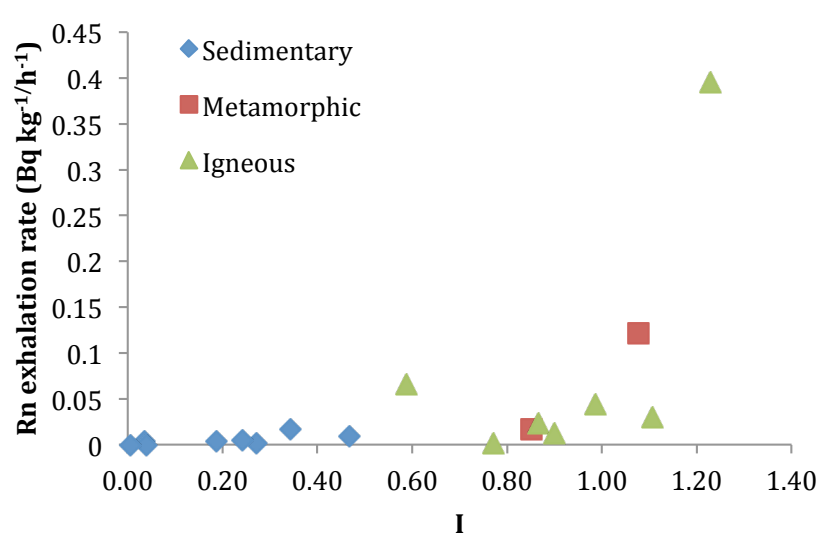

Fig. 8. I parameter, dimensionless, calculated from the measured isotopes and the radon exhalation rate, in $\mathrm{Bq} \mathrm{kg}^{-1} \mathrm{~h}^{-1}$ for the studied samples.

poorly understood by the uninformed public, producing fear, and should be explained in detail.

Fission-track techniques have been used to study the microscopic distribution of uranium in rocks (Kleeman and Lovering, 1967), and these revealed that the above geological processes can effectively induce a redistribution of uranium in the rocks, increasing their ability to promote radon gas exhalation exponentially. In contrast, the confinement of the same chemical element to the structural lattice of the minerals significantly reduces the escape of this gas.

European Radiology Protection Norm 112 describes the maximum value of radiation that building materials can emit with the $I$ index, calculated from the ${ }^{40} \mathrm{~K},{ }^{232} \mathrm{Th}$ and ${ }^{226} \mathrm{Ra}$ activity. A few European countries follow this norm as a safety factor for construction requirements, but in most of them it is not considered. It should be recalled that $I$ is calculated in the scenario of the integral use of the rock (walls, floors and ceilings).

The $I$ index proposed in Norm 112 shows values $<1$ (Fig. 8) for most of our cases, which means that the rocks can be used for any type of building purpose (El-Hussein, 2004). The correlation of the $I$ index with the radon exhalation rate again reveals the positive linear trend between the two variables, which should indicate, as a general rule, the correct applicability of the $I$ index as an estimator of the radiological risk, including radon gas exposure, associated with the use of the rocks studied as building materials.

However, the results obtained in the present study show some deviations from the general trend that deserve more detailed analysis. Despite the recognition of Rojo Sayago and Zamora gneiss as non-recommended for indoor use, the $I$ index is not proportional to the radiological risk derived from the measured radon exhalation rate. Despite this, the parameter is higher than 1 in the case of the Silvestre Dorado sample, but the measured radon exhalation rate does not differ from the variation interval observed in rocks from the same lithological group, with an $I$ index below the action limit. Moreover, the anomalous radon exhalation rate seen for the Rubio Cardeñosa sample seems to be incorrectly reflected by the $I$ index.

The red Rojo Sayago is used only in exterior applications because the mineralogical and textural characteristics of this rock, induced by low temperature hydrothermal alteration and deformation, do not permit it to be used as polished ornamental stone indoors; outside, the exhaled radon would disperse into the surrounding atmosphere. Unfortunately, this is not the recommendation found in commercial catalogues and manuals (García de los Ríos and Báez Mezquita, 2001). Owing to its physical and petrologic characteristics, the gneiss is used as a natural ornamental stone on façades and in paving, with bush hammering and natural endings only on the outside. One particularity of this rock is that it is being exported to France, where the "gneiss de Limoges" is very popular but the quarries are almost exhausted for stone walls. In this case, because the rock is only used outside, the higher $I$ value is harmless. However, in all cases customers should always be informed.

As expected, granites and related lithologies (gneiss) show the highest average $U$ concentrations (Table 2), although within the regular values for such rocks (Rogers and Ragland, 1961; Pavlidou et al., 2006) and without any significant anomalous enrichment.

\section{Conclusions}

Most of the natural stones from Castilla y León studied in this work show $I$ values of less than 1 , which means that they can be used for any type of building purpose. Some of them have values close to zero, these cases being from the sedimentary lithology group. Two samples have higher $I$ values: one is a hydrothermally transformed granite $(I=1.24)$ and the other is a gneiss $(I=1.08)$. However, it is currently uncommon to find entire rooms (ceiling, walls and flooring) made of the same material (mainly because none of these natural stones admits good polishing), and in any case we have observed that these rocks are only used for exterior purposes, not because of their radioactivity, but because of their physical and mechanical properties. This means that the possible radiological impact of our samples is fairly constrained. Granites have traditionally been demonized as the source of natural stone radioactivity. It is true that some granites have higher values for all radiological parameters, but it is also true that most of them have values comparable to those of sedimentary rocks, which are rather low. We obtained the highest $\mathrm{U}$ concentrations in all the igneous and metamorphic rocks. However, on comparing their Rn exhalation, it is seen that most of the values decline to the same values as those seen for the sedimentary rocks. There is the exception again with the Zamora Rojo Sayago and gneiss, which have the highest values for this parameter. Since these two natural stones are 
highly deformed and weathered, it is possible that all deformation structures channel the $\mathrm{Rn}$ to the outside of the stone.

Restricting the use of certain building materials that give high $I$ values can have economic and social consequences, in both the local and national contexts. These consequences, along with the levels of natural radioactivity of building materials, should be addressed at international level. We believe that setting up certain worldwide regulations would be a first step to establishing a guide of good practice in the construction sector. It has been demonstrated that the U content and $\mathrm{Rn}$ exhalation (both from powder and directly from the slab) are not always correlated. In order to make decisions about the influence of the natural radioactivity of natural stones, a complete body of information about all these parameters should be made available.

In any case, and because of the potential importance of this issue in the building sector, the economy and society, more samples of the commercial varieties studied in this work need to be determined in order to confirm the results obtained and the homogeneity of the rocks.

Complete information should be shared with the natural stone companies, and possible restrictions on the use of such rocks throughout the inside of dwellings should be recommended if human health is at risk.

Acknowledgements. PINACAL (consortium of natural stone companies from Castilla y León) is acknowledged for making all the samples available; M. Manteca shared her final project's results with us to complete the data set of the selection. A. Ferrero carried out her final project under the guidance of A. Pereira and D. Pereira, sharing her results with us as well. Nic Skinner is appreciated for his help in polishing the English grammar. Bruce D. Malamud is acknowledged for his suggestions for improving the manuscript. Comments from two anonymous reviewers were appreciated.

Edited by: B. D. Malamud

Reviewed by: two anonymous referees

\section{References}

Abbady, A. G. E.: Estimation of radiation hazard indices from sedimentary rocks in Upper Egipt, Appl. Radiation Isotopes, 60-1, 111-114, 2004.

Ahmed, N. K., Abbady, A., El Arabi, A. M., El-Kamel, A. H., and Abbady, A. G. E.: Comparative study of the natural radioactivity of some selected rocks from Egypt and Germany, Indian J. Pure Appl. Phys., 44, 209-2015, 2006.

Anjos, R. M., Veiga, R., Soares, T., Santos, A. M. A., Aguiar, J. G., Frascá, M. H. B. O., Brage, J. A. P., Uzêda, D., Mangia, L., Facure, A., Mosquera, B., Carvalho, C., and Gomes, P. R. S.: Natural radionuclide distribution in brazilian comercial granites, Radiation Measure., 39, 245-253, 2005.

Cabrera Ceñal, R., Crespo Ramón, J. L., García de los Ríos Cobo, J. I., Mediavilla Manzanal, B., and Armenteros, I.: Mapa Geológico y Minero de Castilla y León. Escala 1:400.000, Junta de Castilla y León, SIEMCALSA, 1997.

Castro, A., Corretgé, L. G., El-Biad, M., El-Hmidi, H., Fernández, C., and Patiño Douce, A.: Experimental Constraints on Hercynian Anatexis in the Iberian Massif, Spain, J. Petrol., 41-10, 1471-1488, 2000.

Chen, J., Moir, D., Pronk, T., Goodwin, T., Janik, M., and Tokonami, S.: An update on Thoron exposure in Canada with simultaneous ${ }^{222} \mathrm{Rn}$ and ${ }^{220} \mathrm{Rn}$ measurements in Fredericton and Halifax, Radiation Protection Dosimetry, 147-4, 541-547, 2011.

Darby, S., Whitley, E., and Howe, G. R.: Radon exposure and cancers other than lung cancer in underground miners: A collaborative analysis of 11 studies, J. Natl. Cancer Inst., 87, 378-384, 1995.

del Arco, M., Carballo, A. M., Holgado, M. J., Martín, C., and Rives, V.: A microporosity study of Villamayor sandstone (Salamanca, Spain), Appl. Clay Sci., 2-4, 375-383, 1987.

El-Hussein, A.: A study on natural radiation exposure in different realistic living rooms, J. Environ. Radioactivity, 79, 355-367, 2004.

European Commission, Radiation Protection 112, Radiological protection Principles concerning the natural radioactivity of building materials, Office for official publications of the European Communities, Luxembourg, ISBN 92-828-8376-0, 2000.

Folk, R. L.: Practical petrographic classification of limestones, Am. Assoc. Petr. Geol. B, 43, 1-38, 1959.

Folk, R. L.: Petrology of Sedimentary Rocks, Hemphill Publishing Company, Austin, TX, 1965.

García de los Ríos, J. I. and Báez Mezquita, J. M.: La Piedra en Castilla y León, Ed. Junta de Castilla y León, 2001 (in Spanish).

Gillmore, G. K. and Jabarivasal, N.: A reconnaissance study of radon concentrations in Hamadan city, Iran, Nat. Hazards Earth Syst. Sci., 10, 857-863, doi:10.5194/nhess-10-857-2010, 2010.

Iñigo, A. C., García-Talegón, J., Trujillano, R., Molina, E., and Rives, V.: Evolution and decay processes in the Villamayor and Zamora sandstones, in: Applied Study of Cultural Heritage and Clays, edited by: Pérez-Rodríguez, J. L., CSIC, Madrid, 47-57, 2003.

Kleeman, J. D. and Lovering, J. F.: Uranium Distribution in Rocks by Fission-Track Registration in Lexan Plastic, Science, 156, 512-513, 1967.

Krewski, D., Rai, S. N., Zielinski, J. M., and Hopke, P. K.: Characterization of Uncertainty and Variability in Residential Radon Cancer Risks Annals of the New York Academy of Sciences, 895-1, 245-272, 2006.

Le Maitre, R. W., Bateman, P., Dudek, A., Keller, J., Lameyre, J., Le Bas, M. J., Sabine, P.A., Schmid, R., Sorensen, H., Streckeisen, A., Woolley, A. R. and Zanettin, B.: A Classification of Igneous Rocks and Glossary of terms: Recommendations of the International Union of Geological Sciences Subcommission on the Systematics of Igneous Rocks, Blackwell Scientific Publications, Oxford, UK, 1989.

Liang, C. F., Paris, P., Sheline, R. K., and Alexa, P.: Alpha decay of ${ }^{221} \mathrm{Rn}$ and ${ }^{217} \mathrm{Po}$; level structure of ${ }^{217} \mathrm{Po}$ and the ${ }^{213} \mathrm{~Pb}$ ground state, Czechoslovak Journal of Physics, 54-2, 189-198, 2004.

Lubin, J. H., Boice Jr., J. D., Edling, C., Hornung, R. W., Howe, G., Kunz, E., Kusiak, R. A., Morrison, H. I., Radford, E. P., Samet, J. M., Tirmarche, M., Woodward, A., Yao, S. X., and Pierce, D. A.: Lung cancer and radon: a joint analysis of 11 underground 
miners studies, US National Institutes of Health, Bethesda MD, Publication No. 94, 3644, 1994.

Manteca, M.: Caracterización Radiológica de las Rocas de Castilla y León, available at: http://gredos.usal.es/jspui/handle/10366/ 108906 (last access: August 2013), 2011 (in Spanish).

Pavlidou, S., Koroneos, A., Papastefanou, C., Christofides, G., Stoulos, S., and Vavelides, M.: Natural radioactivity of granites used as building materials, J. Environ. Radioactivity, 89, 48-60, 2006.

Pereira, D. and Cooper, B.: Building stone as part of a World Heritage site: "Piedra Pajarilla" granite and the city of Salamanca (Spain), in: Stone in Historic Buildings: Characterization and Performance, edited by: Cassar, J., Winter, M. G., Marker, B. R., Walton, N. R. G., Entwisle, D. C., Bromhead, E. N., and Smith, J. W. N., Geological Society, London, Special Publications 391, doi:10.1144/SP391.3, 2013.

Pereira, D., Neves, L., Pereira, A., and González-Neila, C.: Natural radioactivity in ornamental stones: an approach for its study in known samples from Iberia, B. Eng. Geol. Environ. 70, 543-547, 2011.
Rogers, J. J. W. and Ragland, P. C.: Variation of thorium and uranium in selected granitic rocks. Geochim. Cosmochim. Acta, 25, 99-109, 1961.

Schillaci, T., Brai M., Cimino, A., Lo Casto, A., and Sorrentino, F.: Study of capillarity absorption kinetics by XRD CT imaging techniques: a survey on sedimentary rocks of Sicily Conservation Science in Cultural Heritage 8, 91-110, 2008.

SIEMCALSA: La piedra natural en Castilla y León, Junta de Castilla y León, 28 pp., 2008.

UNSCEAR: Sources and Effects of Ionizing Radiation, United Nations Scientific Committee on the Effects of Atomic Radiation, United Nations, New York, 1993.

Whitfield, J. M., Rogers, J. J. W., and Adams, J. A. S.: The relationship between the petrology and the thorium and uranium contents of some granitic rocks, Geochim. Cosmochim. Acta, 17, 248-271, 1959. 